\title{
Production, Purification, and Characterization of a Potential Thermostable Galactosidase for Milk Lactose Hydrolysis from Bacillus stearothermophilus
}

\author{
W. Chen, ${ }^{1}$ H. Chen, Y. Xia, J. Zhao, F. Tian, and H. Zhang \\ State Key Laboratory of Food Science and Technology, School of Food Science and Technology, Jiangnan University, Wuxi 214122, China
}

\begin{abstract}
$\beta$-Galactosidase, commonly named lactase, is one of the most important enzymes used in dairy processing; it catalyzes the hydrolysis of lactose to its constituent monosaccharides glucose and galactose. Here, a thermostable $\beta$-galactosidase gene bga $\mathrm{B}$ from Bacillus stearothermophilus was cloned and expressed in B. subtilis WB600. The recombinant enzyme was purified by a combination of heat treatment, ammonium sulfate fractionation, ion exchange, and gel filtration chromatography techniques. The purified $\beta$-galactosidase appeared as a single protein band in sodium dodecyl sulfate-PAGE gel with a molecular mass of approximately $70 \mathrm{kDa}$. Its isoelectric point, determined by polyacrylamide gel isoelectric focusing, was close to 5.1. The optimum temperature and $\mathrm{pH}$ for this $\beta$-galactosidase activity were $70^{\circ} \mathrm{C}$ and $\mathrm{pH} 7.0$, respectively. Kinetics of thermal inactivation and half-life times for this thermostable enzyme at 65 and $70^{\circ} \mathrm{C}$ were 50 and $9 \mathrm{~h}$, respectively, and the $\mathrm{K}_{\mathrm{m}}$ and $\mathrm{V}_{\max }$ values were $2.96 \mathrm{mM}$ and $6.62 \mu \mathrm{mol} / \mathrm{min}$ per $\mathrm{mg}$. Metal cations and EDTA could not activate this thermostable enzyme, and some divalent metal ions, namely, $\mathrm{Fe}^{2+}, \mathrm{Zn}^{2+}, \mathrm{Cu}^{2+}, \mathrm{Pb}^{2+}$, and $\mathrm{Sn}^{2+}$, inhibited its activity. Thiol reagents had no effect on the enzyme activity, and sulfhydryl group blocking reagents inactivated the enzyme. This enzyme possessed a high level of transgalactosylation activity in hydrolysis of lactose in milk. The results suggest that this recombinant thermostable enzyme may be suitable for both the hydrolysis of lactose and the production of galacto-oligosaccharides in milk processing.
\end{abstract}

Key words: thermostable $\beta$-galactosidase, lactose, purification, hydrolysis

\section{INTRODUCTION}

$\beta$-Galactosidase ( $\beta$-D-galactohydrolase; EC 3.2.1.23) has been used to hydrolyze lactose to produce lactose-

Received August 15, 2007.

Accepted January 8, 2008.

${ }^{1}$ Corresponding author: weichen@jiangnan.edu.cn free milk products and has recently become of interest for the production of galacto-oligosaccharides from lactose by the transgalactosylation reaction (Prenosil et al., 1987; Panesar et al., 2006). Although the yeast Kluyveromyces lactis is still the major commercial source of $\beta$-galactosidase because of its dairy environmental habitat and outstanding lactose hydrolysis activity, $K$. lactis-produced $\beta$-galactosidase has a major drawback in terms of thermostability (Ganeva et al., 2001). In recent years, several types of thermostable $\beta$ galactosidases have been reported (Daabrowski et al., 2000; Lebbink et al., 2000; Wanarska et al., 2005; Synowiecki et al., 2006). Thermostable $\beta$-galactosidases can work at higher temperatures and prevent microbial contamination to some extent in milk processing, functioning under conditions that normally denature mesophilic enzymes (Zeikus et al., 1998). Thus, these thermostable enzymes have considerable industrial potential because they can give better yields at high temperatures.

Many $\beta$-galactosidases from thermophilic microorganisms have been characterized and used for the hydrolysis of lactose and galacto-oligosaccharide production (Panesar et al., 2006). Nevertheless, the production of these enzymes in thermophilic microorganisms is difficult to achieve on an industrial scale, and therefore the possibility of producing them in a mesophilic host using recombinant techniques has become of interest (Bruins et al., 2001; Demirjian et al., 2001; Kang et al., 2005). One of the hosts for large-scale production of foreign proteins is the gram-positive bacterium Bacillus subtilis. The major advantage of this strain is its classification as GRAS (generally recognized as safe), and is an organism free of any endotoxin, so it is favorable in food industry (van Wely et al., 2001).

In our laboratory, the $b g a \mathrm{~B}$ gene from Bacillus stearothermophilus had been expressed in Escherichia coli (Chen et al., 2002a) and its enzymatic activity was characterized; however, its enzymatic half-life at $60^{\circ} \mathrm{C}$ was just $0.5 \mathrm{~h}$. In the present study, the $B$. subtilis expression system was used to evaluate its applicability in thermostable $\beta$-galactosidase production, and the char- 
acteristics of this recombinant thermostable $\beta$-galactosidase were examined after multistep separation for the enzyme purification.

\section{MATERIALS AND METHODS}

\section{Reagents, Microorganisms, and Plasmids}

The restriction endonucleases, T4 DNA ligase, and Pfu DNA polymerase were purchased from Takara Biotech Co. Ltd. (Dalian, China). The Gel Extraction MiniKit and PCR Purification Mini Kit were purchased from Watson Biotechnologies Inc. (Shanghai, China). Other reagents purchased were of analytic grade.

Escherichia coli TG1 was used as host strain for cloning and for the preparation of template plasmids. Bacillus stearothermophilus ATCC8005 was the donor of thermostable $\beta$-galactosidase coding sequence, and $B$. subtilis WB600 was used for expression of $\beta$-galactosidase. The plasmid pBSKII KS+ was the clone vector, and pMA5 was used for construction of the thermostable $\beta$-galactosidase expression plasmid in B. subtilis.

\section{Construction of Expression Vector}

The $b g a \mathrm{~B}$ coding sequence was amplified by PCR with primers U-5'-ATACATATGAATGTGTTATCCTC-3' and D-5'-TATGGATCCCTAAACCTTCCCGGCTTC-3', and then cloned into the pBSKII KS+ vector in accordance with the manufacturer's (Stratagene, La Jolla, $\mathrm{CA})$ protocol to obtain the cloning vector, pBSK-bgaB. Following the digestion with the restriction enzymes NdeI and BamHI (the restriction sites, underlined above, were introduced through PCR primers), the fragment encoding the $b g a \mathrm{~B}$ was recovered, and then inserted between the same sites of $N d e \mathrm{I}$ and $\mathrm{BamHI}$ into pMA5 to obtain the expression vector pMA5-bgaB. The expression vector was then confirmed by restriction endonuclease digestion and sequencing.

\section{Expression of the Recombinant Thermostable $\beta$-Galactosidase}

A fresh clone of $B$. subtilis WB600, harboring the pMA5-bgaB vector, was grown in Luria broth $(\mathbf{L B})$ medium containing $50 \mu \mathrm{g}$ of kanamycin/mL for $12 \mathrm{~h}$. Seed was then taken and inoculated at the ratio of 5\% (volume) into LB medium in a flask or fermenter and fermented at $37^{\circ} \mathrm{C}$ for $18 \mathrm{~h}$; cells were harvested and stored at $-70^{\circ} \mathrm{C}$.

\section{Purification of Thermostable $\beta$-Galactosidase}

The frozen $B$. subtilis WB600/pMA5-bgaB cells were thawed at room temperature and suspended in buffer
A, $20 \mathrm{~m} M$ sodium phosphate ( $\mathrm{pH} 7.0$ ), and then treated with sonication. The supernatant was collected after centrifugation at $4^{\circ} \mathrm{C}$ and $18,522 \times g$ for $20 \mathrm{~min}$ on Beckman J2-21M centrifuge (Beckman Coulter Inc., Fullerton, CA), and then the heating treatment was performed at $65^{\circ} \mathrm{C}$ for $50 \mathrm{~min}$. The solution was subjected to centrifugation at $18,522 \times g$ for $30 \mathrm{~min}$ and the supernatant was collected for enzymatic assay. The clarified supernatant was brought to $30 \%$ ammonium sulfate saturation and centrifuged at $18,522 \times g$ for $30 \mathrm{~min}$. All subsequent fractionation steps involving ammonium sulfate were carried out at $4^{\circ} \mathrm{C}$. After centrifugation, the pellet was discarded and the supernatant was brought to $65 \%$ ammonium sulfate saturation and centrifuged at $18,522 \times \mathrm{g}$ for $30 \mathrm{~min}$ again, and the pellet was dissolved in buffer $\mathrm{B}, 20 \mathrm{mM}$ sodium phosphate ( $\mathrm{pH} 7.5$ ), and dialyzed at $4^{\circ} \mathrm{C}$ for $24 \mathrm{~h}$; further purification was done by anion exchange followed by gel filtration chromatography.

Anion exchange chromatography was performed on an ÄKTA explorer system (Amersham Pharmacia Biotech, Uppsala, Sweden) using a DEAE HiPrep16/10 column and equilibrated with buffer B; the target enzyme was eluted by a linear gradient of 0 to $500 \mathrm{mM} \mathrm{NaCl}$ in buffer B at $2 \mathrm{~mL} / \mathrm{min}$. The effluents and eluents were collected for further evaluation. Gel filtration chromatography was also performed on ÄKTA explorer system using a Sephacryl S-100 HiPrep16/60 column (Amersham Pharmacia Biotech, Uppsala, Sweden). The thermostable $\beta$-galactosidase was eluted in sodium phosphate buffer ( $20 \mathrm{~m} M$ sodium phosphate, $100 \mathrm{~m} M \mathrm{NaCl}$, $\mathrm{pH}=7.0)$ at $1 \mathrm{~mL} / \mathrm{min}$.

\section{PAGE and Protein Quantification}

Electrophoretic analysis of the synthesized products and purified samples was performed in 15\% SDSPAGE, and the gel was stained with Coomassie Brilliant Blue for band visualization. The molecular weight of the purified enzyme was estimated on the basis of migration on $15 \%$ SDS-PAGE.

The protein concentration was determined with Bradford protein assay using BSA as the standard. The percentage of target protein in total protein was quantified by Quantity One software (BioRad Laboratories Inc., Hercules, CA) according to protein band visualization.

\section{Isoelectric Point Estimation}

Isoelectric focusing (IEF) gel electrophoresis was performed using Model 111 mini cell (BioRad) for estimation of isoelectric point according to the protocol provided by the manufacturer. The gel was stained with 
Coomassie Brilliant Blue R-250 to determine the location of the protein bands, and the isoelectric point of the enzyme was estimated by comparing its mobility with the following $\mathrm{pI}$ values of IEF protein markers (BioRad): phycocyanin, $4.7 ; \beta$-LG, 5.1 ; bovine carbonic anhydrase, 6.0; human carbonic anhydrase, 6.5 ; equine myoglobin (minor), 6.8: equine myoglobin (major), 7.0; human hemoglobin A, 7.1; human hemoglobin C, 7.5; lentil lectin (three hands), 7.8, 8.0, and 8.2; and cytochrome c, 9.6.

\section{Enzyme Assay}

The thermostable $\beta$-galactosidases activity was determined as described by Gist-Brocades (Xia et al., 2005), except that the incubation temperature of the enzyme was adjusted to $55^{\circ} \mathrm{C}$. One unit of enzyme activity was defined as the amount of enzyme hydrolyzing 1 micromole of substrate ortho-nitrophenyl- $\beta$-D-galactopyranoside (ONPG) per minute. The specific activity of thermostable $\beta$-galactosidase was expressed in units per milligram of cellular or enzyme protein.

The enzyme activity on lactose in milk was assayed under the same conditions as described above (Xia et al., 2005), and the hydrolysis rate of lactose in milk $(\%)$ was defined as [glucose] $\times 1.9 /[$ lactose] $\times 100$. The released glucose was measured by the glucose oxidaseperoxidase method (Zhao, 2002), and the lactose concentration was determined by Fehling method (Zhao, 2002).

\section{Effect of $\mathrm{pH}$, Temperature, and Various Reagents on Enzyme Activity}

The $\mathrm{pH}$ dependency of enzyme activity was determined at $55^{\circ} \mathrm{C}$ in 2 buffer systems: sodium citrate-phosphate buffer $(200 \mathrm{mM})$ from $\mathrm{pH} 5.0$ to 7.5 and sodium potassium-phosphate buffer $(200 \mathrm{mM}$ ) from $\mathrm{pH} 7.5$ to 9.0. The effect of temperature on enzyme activity was determined at temperatures ranging from 45 to $80^{\circ} \mathrm{C}$. The thermostability of the enzyme was tested by incubation at $60^{\circ} \mathrm{C}$ for $6 \mathrm{~h}, 65^{\circ} \mathrm{C}$ for $5 \mathrm{~h}$, and $70^{\circ} \mathrm{C}$ for $4 \mathrm{~h}$, and aliquots were withdrawn at 0.5 - to 1 -h intervals.

The effect of various reagents on enzyme activity were examined by assaying the residual activity after incubating the enzyme with 1 to $10 \mathrm{~m} M$ of various reagents dissolved in potassium-phosphate buffer (200 $\mathrm{mM}, \mathrm{pH}$ 6.5) for $20 \mathrm{~min}$ at $25^{\circ} \mathrm{C}$. The cations tested were $\mathrm{Li}^{+}, \mathrm{Na}^{+}, \mathrm{K}^{+}, \mathrm{Mg}^{2+}, \mathrm{Ca}^{2+}, \mathrm{Zn}^{2+}, \mathrm{Cu}^{2+}, \mathrm{Fe}^{2+}, \mathrm{Mn}^{2+}$, $\mathrm{Pb}^{2+}$, and $\mathrm{Sn}^{2+}$; the chelating agent, EDTA, the thiol reagents 2-mercaptoethanol and dithiothreitol, and enzyme inhibitors $p$-chloromercuribenzoic acid and iodoacetic acid, were also examined.

\section{Kinetic Analysis}

The kinetic parameters $\left(\mathrm{K}_{\mathrm{m}}\right.$ and $\left.\mathrm{V}_{\max }\right)$ were calculated from Lineweaver-Burk plots using a substrate concentration range of 0.83 to $10 \mathrm{~m} M$ ONPG. All the experiments were carried out at $55^{\circ} \mathrm{C}$ and $\mathrm{pH}$ 7.0.

\section{Amino Acid Composition Analysis}

The AA composition was analyzed by adding $10 \mathrm{~mL}$ of $6 \mathrm{M} \mathrm{HCl}$ and $12.7 \mathrm{mg}$ of the further purified thermostable $\beta$-galactosidases to a hydrolysis vessel, which was kept at $110^{\circ} \mathrm{C}$ for $24 \mathrm{~h}$. Afterward, the $\mathrm{HCl}$ was removed from $1 \mathrm{~mL}$ of sample, and then $1 \mathrm{~mL}$ of 20 $\mathrm{m} M \mathrm{HCl}$ was added. Chromatographic analysis was performed on an Agilent 1100 HPLC system (Agilent, Santa Clara, CA) using a $\mathrm{C}_{18}$ column with a flow rate of $1 \mathrm{~mL} / \mathrm{min}$. The AA of the target enzyme were detected with a UV wavelength of $338 \mathrm{~nm}$.

\section{RESULTS AND DISCUSSION}

\section{Expression Vector Construction of Thermostable $\beta$-Galactosidase and Its Expression in B. subtilis}

For expression the thermostable $\beta$-galactosidase in B. subtilis, an E. coli-B. subtilis shuttle plasmid pMA5 was exploited as backbone to construct the expression vector. To construct expression vector pMA5-bgaB, PCR was performed to introduce restriction sites $N d e \mathrm{I}$ and BamHI to the 5'- and $3^{\prime}$-ends of bgaB gene. The $1 \%$ agarose gel electrophoresis analysis of the PCR product showed the length of the above gene was approximately $2,000 \mathrm{bp}$, in accordance with the calculated length $(2,016 \mathrm{bp})$. The bgaB gene was confirmed for correct orientation using restriction endonuclease digestion and sequencing.

The recombinant strain $B$. subtilis WB600/pMA5bgaB was cultured in $\mathrm{LB}$ medium at $37^{\circ} \mathrm{C}$ for $18 \mathrm{~h}$, and the cells were harvested and treated with sonication to determine enzymatic activity. Results showed that thermostable $\beta$-galactosidase was expressed and the enzymatic activity reached $5.8 \mathrm{U} / \mathrm{mg}$ of protein, more than 45 times of that obtained from B. stearothermophilus $(0.1 \mathrm{U} / \mathrm{mg}$ of protein; Hirata et al., 1986).

\section{Purification of Thermostable $\beta$-Galactosidase}

Because the recombinant $\beta$-galactosidase is a thermostable enzyme, the crude enzyme solution was first treated with heating at $65^{\circ} \mathrm{C}$ for $50 \mathrm{~min}$. After ammonium sulfate precipitation, the enzyme was further separated by 2 -step purification in which the anion exchange chromatography was followed by gel filtration. 
Table 1. Summary of the thermostable $\beta$-galactosidase purification from recombinant Bacillus subtilis

\begin{tabular}{|c|c|c|c|c|c|}
\hline Step & $\begin{array}{l}\text { Total protein } \\
\text { (mg) }\end{array}$ & $\begin{array}{l}\text { Total activity } \\
\text { (U) }\end{array}$ & $\begin{array}{l}\text { Specific activity } \\
(\mathrm{U} / \mathrm{mg})\end{array}$ & $\begin{array}{c}\text { Yield } \\
(\%)\end{array}$ & $\begin{array}{l}\text { Purification } \\
\quad \text { (fold) }\end{array}$ \\
\hline Cell-free extract & $20,580.5$ & $133,350.3$ & 6.5 & 100.0 & 1.0 \\
\hline Heat treatment & $7,100.1$ & $133,000.6$ & 18.7 & 99.7 & 2.9 \\
\hline Anion exchange (DEAE) & 680.9 & $72,400.7$ & 106.4 & 54.3 & 16.4 \\
\hline Gel filtration (Sephacryl S-100) & 209.3 & $26,200.3$ & 125.2 & 19.7 & 19.4 \\
\hline
\end{tabular}

The final enzyme activity reached $125.2 \mathrm{U} / \mathrm{mg}$ of protein (higher than that reported in Hirata et al., 1985) and the purity reached about $95.1 \%$. The purification procedures and results of the thermostable $\beta$-galactosidase are summarized in Table 1, which depicts specific activity and the purification fold of every step. An overall recovery of $19.7 \%$ and a 19.4 -fold enrichment of the recombinant enzyme were obtained after 4 steps. The enzyme samples of every purification step were subjected to $15 \%$ SDS-PAGE analysis, and the final purified thermostable $\beta$-galactosidase showed a single band of about $70 \mathrm{kDa}$ (Figure 1). Its molecular weight was in accordance with that reported by Hirata et al. (1985), but lower than the molecular weight of $78 \mathrm{kDa}$ deduced from the AA sequence. It is possible that the recombinant enzyme is modified by the host $B$. subtilis.

\section{Molecular Properties}

The isoelectric point of the thermostable $\beta$-galactosidase, estimated by IEF on a typical analytical IEF polyacrylamide gel, was in the range of 4.7 to 5.1. It was lower than the calculated value of 5.7, and similar to most of the reported $\mathrm{pI}$ for thermostable $\beta$-galactosidases (4.1 to 4.5) (Onishi and Tanaka, 1995).

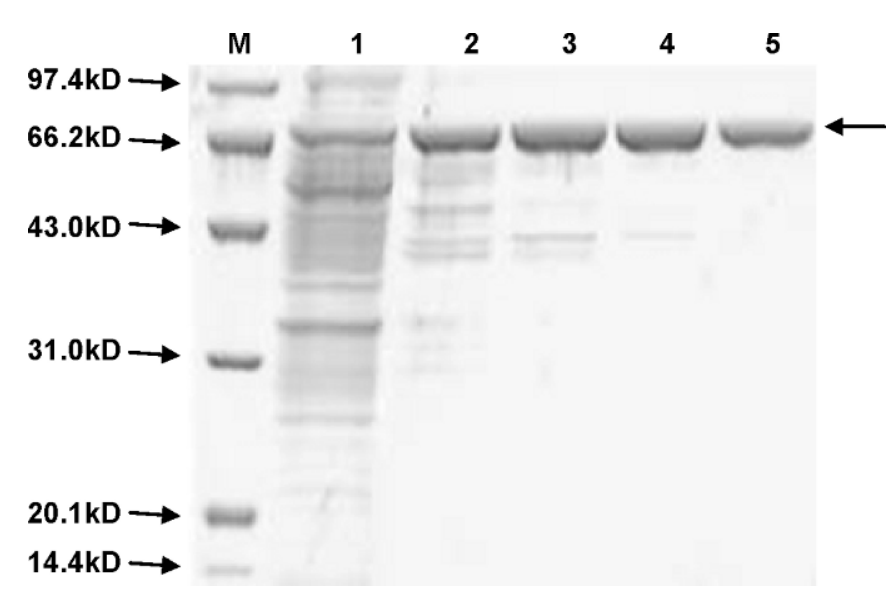

Figure 1. Sodium dodecyl sulfate-PAGE analysis of the purified thermostable $\beta$-galactosidase from different stages. $\mathrm{M}=$ protein marker; lane 1 = cell-free extract; lane 2 = fraction of heat treatment; lane 3 = fraction of $\left(\mathrm{NH}_{4}\right)_{2} \mathrm{SO}_{4}$ precipitation; lane $4=$ fraction of ÄKTA DEAE column; lane 5 = fraction of ÄKTA Sephacryl S-100 column.
The AA composition is indicated in Table 2. From the 17 kinds of AA, the determined weight percentage of Asp and Glu were greater than the calculated value, whereas the weight percent of the other AA were similar to the calculated values, especially for Ala, Val, Leu, and Ile, the side-acyclic AA. The AA Ala, Val, Leu, and Ile are very helpful for the thermostability of $\beta$ galactosidase (He et al., 2000).

\section{Enzyme Properties}

pH and Temperature Profiles of the Enzymes. The $\mathrm{pH}$ profile of the thermostable $\beta$-galactosidase activity is shown in Figure 2. The enzyme displayed its maximum activity at $\mathrm{pH}=7.0$ and retained more than $80 \%$ of its activity at a $\mathrm{pH}$ range of 6.0 to 7.5. This optimal $\mathrm{pH}$ range is a good property with respect to milk processing because it is near to $\mathrm{pH}=6.7$ of normal bovine milk.

The effect of temperature on the enzyme activity was studied at temperatures ranging from 45 to $80^{\circ} \mathrm{C}$ at $\mathrm{pH}=7.0$ (Figure 3). This thermophilic enzyme showed the maximum activity at $70^{\circ} \mathrm{C}$, which was double that obtained at $55^{\circ} \mathrm{C}$, and retained $80 \%$ of its activity even at $75^{\circ} \mathrm{C}$. Thermostability was determined by treating the enzyme at 60,65 , and $70^{\circ} \mathrm{C}$ (Figure 4). Results revealed that the enzymatic half-life at these 3 temperatures were 120,50 , and $9 \mathrm{~h}$, respectively, higher than the data reported (Hirata et al., 1985; Wei et al., 2001). The enzymatic half life of recombinant $\beta$-galactosidase from $B$. subtilis is much greater than that from $E$. coli (Chen et al., 2002b), which may due to the greater homogeneity between $B$. subtilis and $B$. stearothermophilus than between $E$. coli and $B$. stearothermophilus. The favorable temperature activity of this enzyme and its thermostability are desirable properties for normal lactose-free and lactose-reduced milk processing.

Effects of Metal Cations, EDTA, Thiol Reagents, and Enzyme Inhibitors on Enzyme Activity. The cations $\mathrm{Fe}^{2+}, \mathrm{Zn}^{2+}, \mathrm{Cu}^{2+}, \mathrm{Pb}^{2+}$, and $\mathrm{Sn}^{2+}$ inhibited 52, $76.6,85.3,100$, and $100 \%$ of the enzyme activity, respectively, whereas other metal cations and EDTA did not (Table 3). Therefore, no metal cations are required for enzyme activity according to these results. The sulfhydryl group-blocking reagents $p$-chloromercuribenzoic 
Table 2. Amino acid composition of the thermostable $\beta$-galactosidase

\begin{tabular}{lcccc}
\hline $\begin{array}{l}\text { Amino } \\
\text { acid }\end{array}$ & $\begin{array}{c}\text { Number count } \\
\text { (calculated) }\end{array}$ & $\begin{array}{c}\text { \% by frequency } \\
\text { (calculated) }\end{array}$ & $\begin{array}{c}\text { \% by weight } \\
\text { (calculated) }\end{array}$ & $\begin{array}{r}\text { \% by weight } \\
\text { (determined) }\end{array}$ \\
\hline Ala & 36 & 5.35 & 3.55 & 4.19 \\
Arg & 36 & 5.35 & 6.95 & 6.90 \\
Asp & 40 & 5.94 & 5.90 & 16.09 \\
Cys & 10 & 1.49 & 1.34 & 0.84 \\
Gly & 43 & 6.39 & 3.58 & 5.69 \\
Glu & 51 & 7.58 & 8.31 & 13.55 \\
His & 19 & 2.82 & 3.27 & 2.18 \\
Ile & 48 & 7.13 & 6.98 & 6.54 \\
Lys & 38 & 5.65 & 6.15 & 8.04 \\
Leu & 52 & 7.73 & 7.56 & 1.83 \\
Met & 15 & 2.23 & 2.48 & 5.44 \\
Phe & 29 & 4.31 & 5.31 & 4.20 \\
Pro & 37 & 5.50 & 4.72 & 2.37 \\
Ser & 29 & 4.31 & 3.38 & 3.73 \\
Thr & 25 & 3.71 & 3.30 & 6.28 \\
Val & 49 & 7.28 & 6.36 & 6.08 \\
Tyr & 35 & 5.20 & 7.02 & ND \\
Asn & 38 & 5.65 & 5.56 & ND \\
Gln & 21 & 3.12 & 3.40 & ND $^{1}$ \\
Trp & 21 & 3.12 & 4.75 & \\
\hline
\end{tabular}

${ }^{1} \mathrm{ND}=$ not determined.

acid and iodoacetic acid inhibited 86.2 and $73.0 \%$ of the enzyme activity, respectively, indicating that a sulfhydryl group is involved at or near the active domain of this recombinant thermostable $\beta$-galactosidase. Furthermore, the thiol reagents 2-mercaptoethanol and dithiothreitol had no distinct promotion effect on enzyme activity, showing that intact disulfide groups are not important for enzyme activity.

Novel Kinetic Properties with Substrate or Substrate-Like Activation. The enzyme kinetic parameters for ONPG or other substrate-like inhibitors were

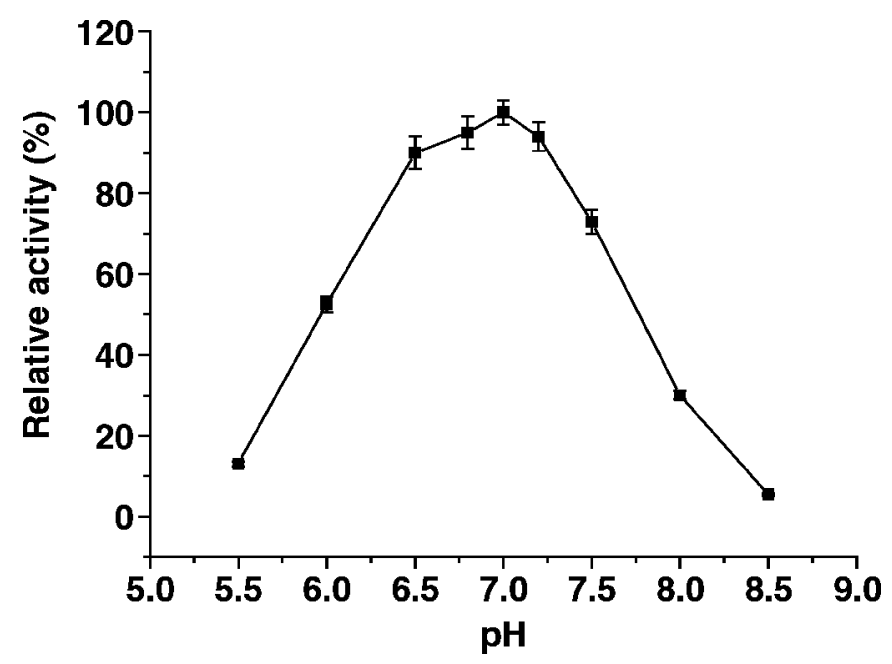

Figure 2. Effect of $\mathrm{pH}$ on activity of the recombinant $\beta$-galactosidase. Error bars represent the standard deviation from 3 separate experiments. calculated from a Lineweaver-Burk plot. The $\mathrm{K}_{\mathrm{m}}$ and $\mathrm{V}_{\max }$ values for ONPG were $2.96 \mathrm{~m} M$ and $6.62 \mu \mathrm{mol} /$ min per $\mathrm{mg}$ (Figure 5). The substrate-like inhibitors, lactose $(10 \mathrm{mM})$, galactose $(100 \mathrm{mM})$, melibiose $(100$ $\mathrm{m} M)$ and melitriose $(100 \mathrm{~m} M)$, known to be potent substrate inhibitors of many $\beta$-galactosidases in an ONPG system (Chen, 2001), were added to obtain the inhibitor constant value $K_{i}$ according to the inhibitor substrate concentration. The results showed that lactose and galactose had a competitive inhibitor effect against ONPG (Figure 6). The inhibitory activity of lactose was greater

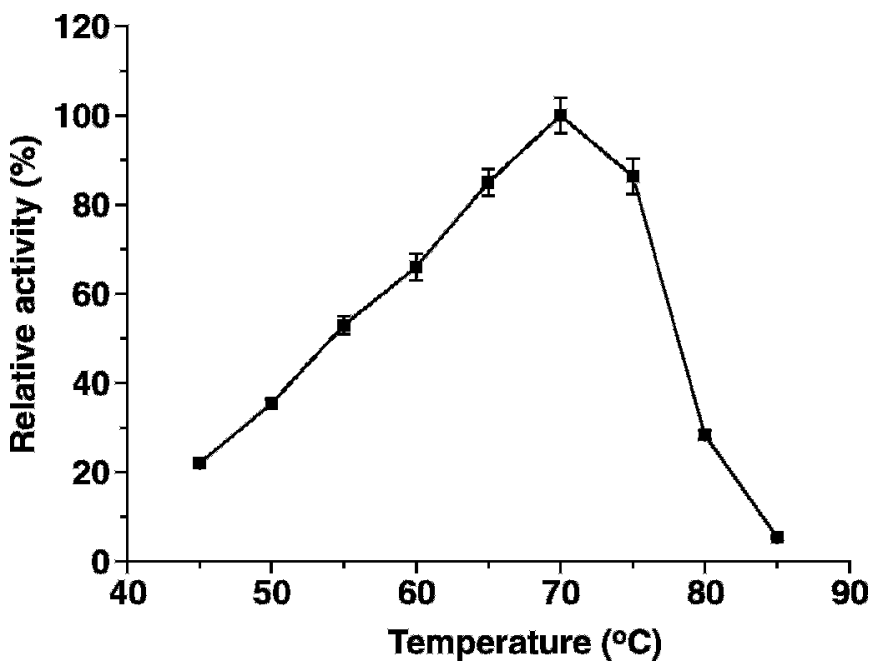

Figure 3. Effect of temperature on activity of the recombinant $\beta$ galactosidase. Error bars represent the standard deviation from 3 separate experiments. 


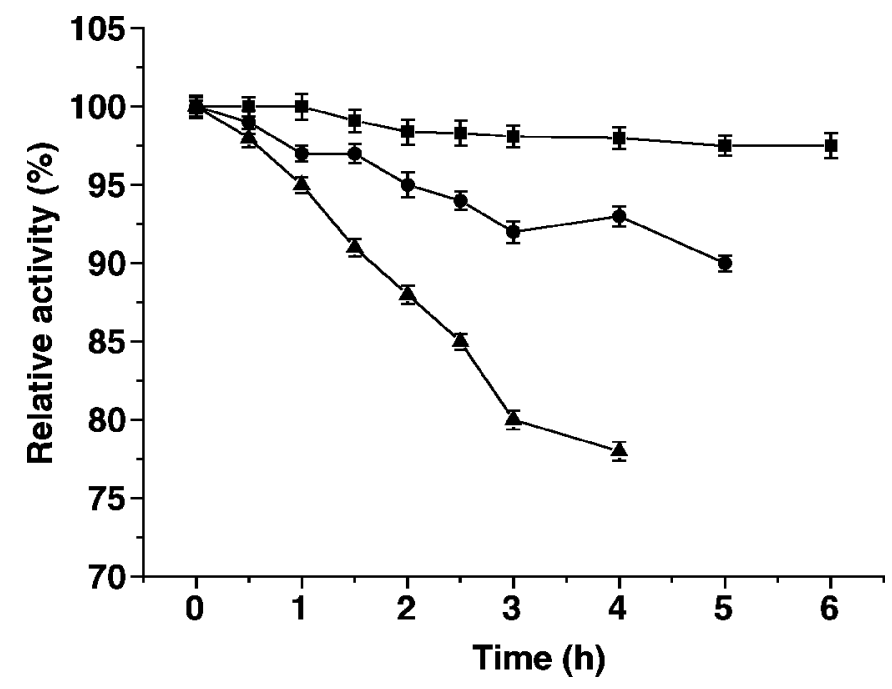

Figure 4. The thermostability of $\beta$-galactosidase from Bacillus subtilis WB600/pMA5-bgaB at different temperatures: $\mathbf{\square}=60^{\circ} \mathrm{C} ; \mathbf{O}=$ $65^{\circ} \mathrm{C} ; \boldsymbol{\Lambda}=70^{\circ} \mathrm{C}$. Error bars represent the standard deviation from 3 separate experiments.

than galactose: the $K_{i}$ was 15.7 and $87.3 \mathrm{~m} M$ for lactose and galactose, respectively.

Hydrolysis of Lactose in Milk by Thermostable $\beta$-Galactosidase. The ability of thermostable $\beta$-galactosidase to catalyze lactose for producing D-glucose was tested with hydrolysis of lactose in milk at different

Table 3 Effects of metal cations, EDTA, thiol reagents, and enzyme inhibitors on the thermostable $\beta$-galactosidase activity $(\mathrm{n}=4)$

\begin{tabular}{lcc}
\hline & $\begin{array}{c}\text { Concentration } \\
(\mathrm{m} M)\end{array}$ & $\begin{array}{c}\text { Relative } \\
\text { activity } \\
(\%)\end{array}$ \\
\hline Control & 0 & $100.0^{\mathrm{a}}$ \\
Cations & 10 & $97.5^{\mathrm{a}}$ \\
$\mathrm{Li}^{+}$ & 10 & $100.0^{\mathrm{a}}$ \\
$\mathrm{Na}^{+}$ & 10 & $103.6^{\mathrm{a}}$ \\
$\mathrm{K}^{+}$ & 10 & $109.0^{\mathrm{a}}$ \\
$\mathrm{Mg}^{2+}$ & 10 & $95.0^{\mathrm{a}}$ \\
$\mathrm{Ca}^{2+}$ & 5 & $23.4^{\mathrm{b}}$ \\
$\mathrm{Zn}^{2+}$ & 5 & $14.7^{\mathrm{b}}$ \\
$\mathrm{Cu}^{2+}$ & 5 & $48.0^{\mathrm{c}}$ \\
$\mathrm{Fe}^{2+}$ & 2 & $102.0^{\mathrm{a}}$ \\
$\mathrm{Mn}^{2+}$ & 2 & $0.0^{\mathrm{d}}$ \\
$\mathrm{Pb}^{2+}$ & 2 & $0.0^{\mathrm{d}}$ \\
$\mathrm{Sn}^{2+}$ & & \\
$\mathrm{Chelating}^{2+}$ agents & 1 & $97.4^{\mathrm{a}}$ \\
EDTA & 1 & $117.5^{\mathrm{a}}$ \\
Thiol reagents & 1 & $125.0^{\mathrm{a}}$ \\
$2-m e r c a p t o e t h a n o l$ & 1 & $13.8^{\mathrm{b}}$ \\
Dithithreitol & 1 & $27.0^{\mathrm{b}}$ \\
Enzyme inhibitors & & \\
PCMB & & \\
Iodoacetic acid & &
\end{tabular}

${ }^{\mathrm{a}-\mathrm{d}}$ Means within the column with different superscripts differ $(P$ $<0.05)$.

${ }^{1} \mathrm{PCMB}=p$-chloromercuribenzoic acid.

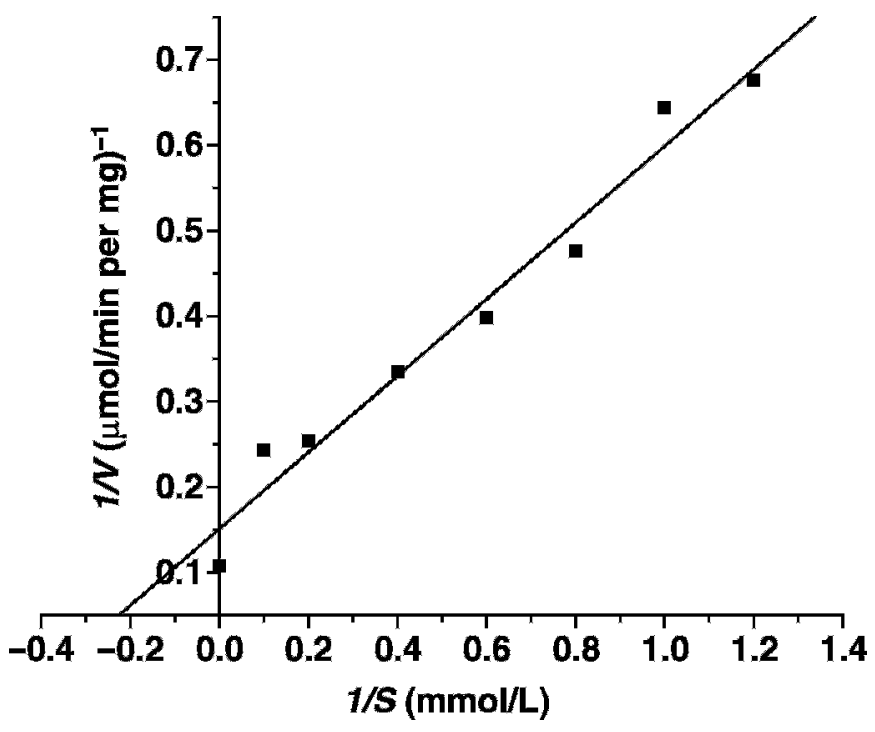

Figure 5. Lineweaver-Burk plot of the thermostable $\beta$-galactosidase.

temperatures using different amounts of the recombinant enzyme. The determination of the D-glucose/ $\beta$-galactosidase ratio (hydrolysis rate) as a function of the reaction time provides a good estimate of the extent that transgalactosylation (to lactose or D-galactose receptors) competes with complete hydrolysis during lactose conversion. The maximum value for the hydrolysis rate was $100 \%$ when using $2 \mathrm{U}$ of thermostable $\beta$-galac-

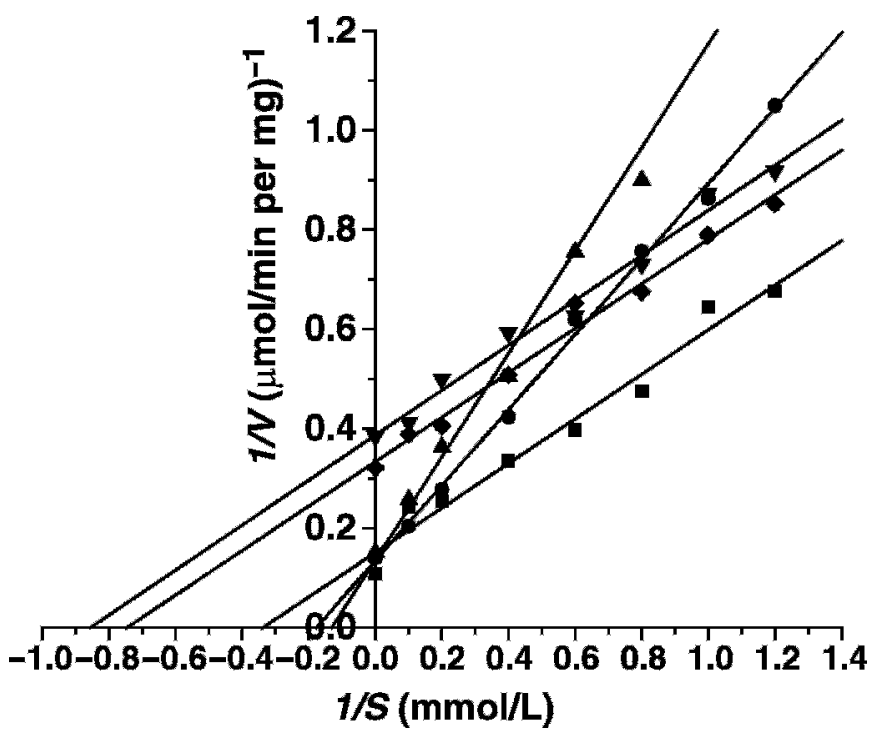

Figure 6. Effect of substrate-like inhibitors on the activity of thermostable $\beta$-galactosidase: $\mathbf{D}=$ control; $\boldsymbol{\Delta}=$ lactose $(10 \mathrm{mM}) ; \boldsymbol{O}=$ galactose $(100 \mathrm{mM}) ; \boldsymbol{\nabla}=$ melibiose $(100 \mathrm{mM}) ; \diamond=$ melitriose $(100 \mathrm{mM})$. 


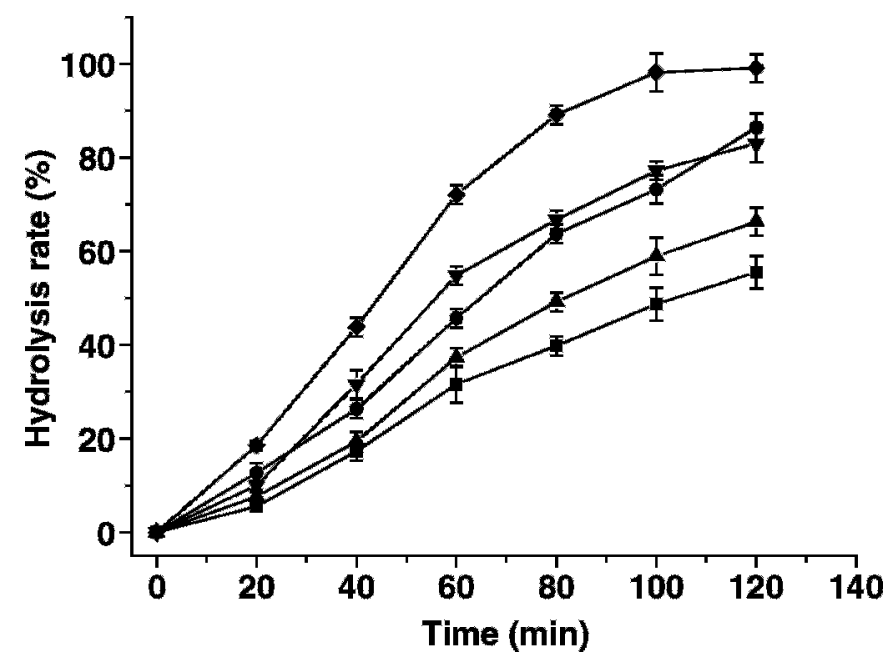

Figure 7. Hydrolysis of lactose in milk by thermostable $\beta$-galactosidase: $\mathbf{\square}=55^{\circ} \mathrm{C}, 1 \mathrm{U} / \mathrm{mL} ; \boldsymbol{\bullet}=55^{\circ} \mathrm{C}, 2 \mathrm{U} / \mathrm{mL} ; \boldsymbol{\Delta}=60^{\circ} \mathrm{C}, 1 \mathrm{U} / \mathrm{mL} ; \boldsymbol{\nabla}=$ $65^{\circ} \mathrm{C}, 1 \mathrm{U} / \mathrm{mL} ;=65^{\circ} \mathrm{C}, 2 \mathrm{U} / \mathrm{mL}$. Error bars represent the standard deviation from 3 separate experiments.

tosidase $/ \mathrm{mL}$ at $65^{\circ} \mathrm{C}$ (Figure 7). Note that the hydrolysis rate of lactose in milk went up when the reaction temperature and $\beta$-galactosidase amounts increased, and also increased with time. These results showed that the thermostable $\beta$-galactosidase from $B$. subtilis that has been produced using recombinant techniques has a high level of transgalactosylation activity.

The thermostable $\beta$-galactosidase gene from $B$. stearothermophilus, which was expressed in recombinant $B$. subtilis, was first reported by Hirata et al. (1985). We analyzed enzyme kinetics with substrate-like inhibitors, metal cations, EDTA, thiol reagents, and enzyme inhibitors and showed that this recombinant enzyme is generally effective in hydrolyzing lactose in milk.

One of the general methods for milk pasteurization is the low-temperature, long-time process, which involves heating the milk to a temperature between 62.8 and $65.6^{\circ} \mathrm{C}$ for $30 \mathrm{~min}$ (Robinson, 1994). Considering the molecular properties, temperature profiles, and its hydrolytic activity of lactose in milk, the thermostable $\beta$ galactosidase has a potential for enzyme application in low-lactose milk production during the low-temperature, long-time process. In addition, $B$. subtilis is recognized as safe organism free of any endotoxin. Therefore, the thermostable $\beta$-galactosidase from $B$. subtilis is well suited for direct application to lactose hydrolysis during milk pasteurization.

\section{CONCLUSIONS}

Extensive studies on thermostable $\beta$-galactosidases and their recombinant production have been carried out previously (Panesar et al., 2006). Almost all the thermostable $\beta$-galactosidases have so far been found in thermophilic and thermotolerant microorganisms. This paper reports the purification and characterization of a recombinant thermostable $\beta$-galactosidase with a high level of transgalactosylation activity. The enzyme is active at high temperatures up to $75^{\circ} \mathrm{C}$ and also shows a high level of thermostability. The enzyme has a molecular weight of about $70 \mathrm{kDa}$ and its optimum $\mathrm{pH}$ is 7.0 . Some divalent cations $\mathrm{Fe}^{2+}, \mathrm{Zn}^{2+}, \mathrm{Cu}^{2+}, \mathrm{Pb}^{2+}$, and $\mathrm{Sn}^{2+}$ can inhibit the enzyme activity from 52 to $100 \%$ (inhibition ratio), and EDTA does not activate it. The enzyme includes a sulfhydryl group around the enzyme active site and intact disulfide groups are not essential for enzyme activity. In addition, its isoelectric point is near 5.1 and the $\mathrm{K}_{\mathrm{m}}$ and $\mathrm{V}_{\max }$ values for $\mathrm{ONPG}$ at $55^{\circ} \mathrm{C}$ are $2.96 \mathrm{mM}$ and $6.62 \mu \mathrm{mol} / \mathrm{min}$ per $\mathrm{mg}$. The enhanced stability properties of this recombinant thermostable $\beta$-galactosidase, combined with its neutral $\mathrm{pH}$ activity and favorable temperature activity optima, suggest that the enzyme is an ideal candidate for the hydrolysis of lactose in milk, and would be suitable for application in low-lactose milk production during milk pasteurization.

\section{ACKNOWLEDGMENTS}

This work was financially supported by National Natural Science Foundation of China (No. 30670065) and the National High Technology Research and Development Program of China (No. 2007AA10Z316).

\section{REFERENCES}

Bruins, M. E., A. E. Janssen, and R. M. Boom. 2001. Thermozymes and their applications: A review of recent literature and patents. Appl. Biochem. Biotechnol. 90:155-186.

Chen, S. 2001. Studies on process engineering of galacto-oligosaccharides synthesis by beta-galactosidase from $B$. stearothermophilus. $\mathrm{PhD}$ thesis. East China University of Science and Technology, Shanghai, China.

Chen, W., H. Zhang, and X. Ding. 2002b. Study on properties of thermostable $\beta$-galactosidase and hydrolysis of lactose in milk. China Dairy Ind. 30:15-18.

Chen, W., H. Zhang, J. Ge, and X. Ding. 2002a. High-level expression of thermostable galactosidase gene in Escherichia coli. Biotechnology (N.Y.) 12:8-11.

Daabrowski, S., G. Sobiewska, J. Maciunska, J. Synowiecki, and J. Kur. 2000. Cloning, expression, and purification of the His(6)tagged thermostable beta-galactosidase from Pyrococcus woesei in Escherichia coli and some properties of the isolated enzyme. Protein Expr. Purif. 19:107-112.

Demirjian, D. C., F. Moris-Varas, and C. S. Cassidy. 2001. Enzymes from extremophiles. Curr. Opin. Chem. Biol. 5:144-151.

Ganeva, V., B. Galutzov, and N. Eynard. 2001. Electroinduced extraction of $\beta$-galactosidase from Kluyveromyces lactis. Appl. Microbiol. Biotechnol. 56:411-413.

He, Z., Q. Peng, and J. Chen. 2000. Thermophiles Biology. Science Press, Beijing, China.

Hirata, H., T. Fukazawa, S. Negoro, and H. Okada. 1986. Structure of a $\beta$-galactosidase gene of Bacillus stearothermophilus. J. Bacteriol. 166:722-727. 
Hirata, H., S. Negoro, and H. Okada. 1985. High production of thermostable beta-galactosidase of Bacillus stearothermophilus in Bacillus subtilis. Appl. Environ. Microbiol. 49:1547-1549.

Kang, S. K., K. K. Cho, J. K. Ahn, J. D. Bok, S. H. Kang, J. H. Woo, H. G. Lee, S. K. You, and Y. J. Choi. 2005. Three forms of thermostable lactose-hydrolase from Thermus sp. IB-21: Cloning, expression, and enzyme characterization. J. Biotechnol. 116:337-346.

Lebbink, J. H., T. Kaper, P. Bron, J. van der Oost, and W. M. de Vos. 2000. Improving low-temperature catalysis in the hyperthermostable Pyrococcus furiosus beta-glucosidase CelB by directed evolution. Biochemistry 39:3656-3665.

Onishi, N., and T. Tanaka. 1995. Purification and properties of a novel thermostable galacto-oligosaccharide-producing beta-galactosidase from Sterigmatomyces elviae CBS8119. Appl. Environ. Microbiol. 61:4026-4030.

Panesar, P. S., R. Panesar, R. S. Singh, J. F. Kennedy, and H. Kumar. 2006. Microbial production, immobilization, and applications of beta-D-galactosidase. J. Chem. Technol. Biotechnol. 81:530-543.

Prenosil, J. E., E. Stuker, and J. R. Bourne. 1987. Formation of oligosaccharides during enzymatic lactose hydrolysis. Part I: State of art. Biotechnol. Bioeng. 30:1019-1025.
Robinson, R. K. 1994. Modern Dairy Technology, Vol. 1. 2nd ed. Chapman \& Hall, London, UK.

Synowiecki, J., B. Grzybowska, and A. Zdzieblo. 2006. Sources, properties and suitability of new thermostable enzymes in food processing. Crit. Rev. Food Sci. 46:197-205.

van Wely, K. H. M., J. Swaving, R. Freudl, and A. J. M. Driessen. 2001. Translocation of proteins across the cell envelope of Grampositive bacteria. FEMS Microbiol. Rev. 25:437-454.

Wanarska, M., J. Kur, R. Pladzyk, and M. Turkiewicz. 2005. Thermostable Pyrococcus woesei beta-D-galactosidase-high level expression, purification and biochemical properties. Acta Biochim. Pol. 52:781-787.

Wei, D., S. Chen, X. Wang, Q. Yuan, and J. Yu. 2001. Properties of beta-galactosidase from Bacillus stearothermophilus. Microbiology 28:19-21.

Xia, Y., W. Chen, X. Fu, H. Zhang, S. Yang, and X. Ding. 2005. Construction of an integrative food-grade expression system for Bacillus subtilis. Food. Res. Int. 38:251-256.

Zeikus, J. G., C. Vieille, and A. Savchenko. 1998. Thermozymes: Biotechnology and structure-function relationships. Extremophiles 2:179-183.

Zhao, Y. 2002. The Principle of Biochemical Technology and Its Application. 3rd ed. Science Press, Beijing, China. 